\title{
Professional Traits And Skills: First-Year Teachers Principals Like To Hire
}

\author{
Craig D. Kono, Northern State University, USA
}

\begin{abstract}
The purpose of this paper was to survey South Dakota school administrators and identify a set of professional traits and skills that K-12 school principals most value when they hire first-year teachers for their classrooms. The participants were elementary and secondary school principals across rural South Dakota. Eighty-four principals were sent the electronic survey, and forty-five principals responded in April and May of 2009. This survey was conducted by the Northern State University Teacher Induction Program a data collection and follow-up support program for new teachers graduating from Northern State University and entering their first year of teaching. The results of the data collection documents trends and issues to be addressed by NSU School of Education.
\end{abstract}

Keywords: Induction, first-year teacher, Northern State University, new teacher traits and skills, dispositions

\section{INTRODUCTION}

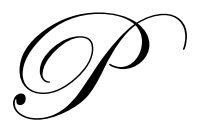

rincipals in elementary and secondary schools throughout rural South Dakota are always looking for innovative new teachers to hire for their school's teaching vacancies. All principals consistently seek out energetic, vibrant first-year teachers to become strong leaders in the classroom, and positive, dynamic, professional influences throughout the local school community. The question is which characteristics are most highly prized by school principals and considered the most essential for success for the new teachers they hire?

What exactly are the most prized traits school principals are looking for? Hopkins (2009) asked a group of principals which traits were most sought after in new teachers, and the responses he received included passion, compassion, heart, good interpersonal skills, and a sense of humor. Steven Podd, principal at Islip (N.Y.) Middle School says, "The one quality I try to find is a teacher who will be a "kid magnet." Our committee just finished interviewing 26 candidates, and we found three or four with those qualities." Podd continued to say, "All committee members agreed that the final candidates have that special something to become superstars - and we will settle for nothing less!" Mary Ellen Imbo, principal at Westwood Elementary School in Broken Arrow, Oklahoma stated, "Stephen Covey (Seven Habits of Highly Effective People) says "any job is twenty percent knowledge and eighty percent interpersonal skills." "I am interested in discerning which interpersonal skills a candidate possesses that will 'connect' with the student. This connection -- this caring attitude -- motivates learners to learn." Gary Cardwell of Crockett Elementary School in Wichita, Texas noted, "It is impossible to select one characteristic that sets a teacher candidate apart from all the others."

Robert Glenn (2001) collected a series of fifteen traits for the National Education Association, and says. "Education is not an exact science and the qualities that are needed in teaching personnel will vary depending on different objectives and needs of schools. However, the characteristics that are listed below are the ones that conscientious administrators will be seeking."

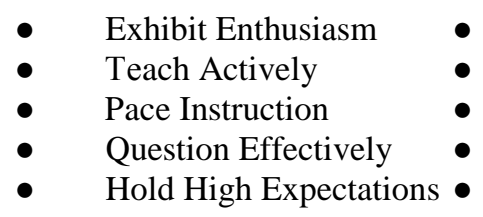

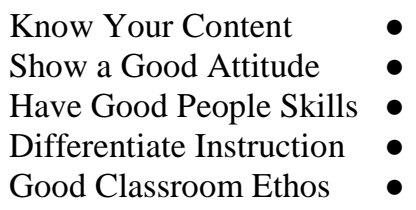

\author{
Be Organized \\ Classroom Management \\ Communicate Clearly \\ Build Success in Class \\ Be Flexible
}


According to Shaw (2003) "principals hire teachers who exhibit the knowledge, skills, and dispositions they value. Therefore the school will be a reflection of those merits. Knowing what a school values, and evaluating your strengths and weaknesses within this context, prepares you for an interview." Shaw asked three principals with varying amounts of school administration experience what three things they looked for in a new teacher:

\section{8-Year Elementary Principal}

- Demonstrates the ability to think "big picture"

- Understands best practices

- Possesses good interpersonal skills

\section{3-Year Middle School Principal}

- Shows an ability to teach standards-based curriculum

- Exhibits openness to working with any child at any academic level

- Demonstrates flexibility and creativity

\section{8-Year High School Principal}

- Likes kids and gets along with them

- Exhibits passion and energy

- Knows subject content

International principals also like to hire new teachers with sets of values and beliefs that are similar to their own. In their article, Principals Hire the Beginning Teachers They Like, Guy and Kathy Broadley (2003) cite studies by Cameron and Grunhoff (1992) and Broadley and Renault (1996). Their research found that state employers in New Zealand also looked for beginning teachers with qualities that match those in the United States. "In the final analysis, it is whether or not the applicant is compatible with the views and values of the principal." From their interviews with eight New Zealand principals, they created a list of primary traits that New Zealand principals wanted in beginning teachers:

- Management

- Teamwork
- School Ethos

- Child Focus
- Community

- Maturity
- Commitment

- Enthusiasm

Principals in South Dakota also tended to hire first-year teachers that have similar traits they value. Peggy Heinz, former elementary principal at Washington and Jefferson Elementary schools in Huron, South Dakota says, "What I looked for in a fresh "out of the box" teacher was, are they a go-getter? I like to hire a first year teacher who might not have all the experience as a veteran teacher but is willing to go above and beyond to get there! We hired for personality and trained for skill, I believe if you can fit the personality to the job you can work out the rest. It is all attitude, attitude, attitude!" Dr. Rod Weber, superintendent and high school principal at Woonsocket School District in South Dakota states, "In my experience as principal, the most important and significant trait that I consider when hiring a first-year teacher is personality. I believe that a teacher's personality and the relationship they can develop with their students is one of the most influential components in classroom success."

Some school Principals in South Dakota look for new teachers that can manage communications with parents, have a strong work ethic, effective organizational skills, and the patience to manage changes in school curriculum and educational technology. Jennifer Knecht, elementary principal at the Faulkton School District says, "A new teacher must have the confidence and willingness to be in constant contact with parents, especially if a child is having difficulty. We have great kids here in South Dakota, and parents want the best for their children now and for their future. Another trait that is so important to new teachers is the ability to manage their work load. Recently, I had a new teacher, who did not make it past year three. She was so overwhelmed with all the "WORK" teachers have to do. The job took over her life, largely because she did not have the organizational skills to handle everything teaching requires. New teachers must make sure that they are serving these children well by having well run classrooms and that they are presenting relevant grade level information to all students, that also includes changes in federal curriculum mandates and new classroom technology." 
Other principals in South Dakota said they are looking for first-year teachers that connect with students, and others wanted new teachers with a passion and commitment for teaching, and learning. Timothy Kosters, principal at Lead-Deadwood Elementary School in Deadwood, South Dakota commented, "One of our second grade teachers always says, "Kids don't care what you know until they know you care." I try to look for first-year teachers that are going to be flexible and willing to go the extra mile to meet the needs of our students." Trent Osborne, principal at Ipswich High School remarked, "I look for a person whose attitude says, 'I GET to work with students every day." Mark Murphy, assistant principal at Aberdeen Central High School in Aberdeen South Dakota added, "Passion! They must want to teach each child in their room every day. New teachers must be excited about the profession they have chosen and have the eagerness to get started. They must have a confident attitude and a belief that education is the noblest of all professions."

\section{DATA COLLECTION}

This study was created by the Teacher Induction Program at Northern State University, a small liberal arts university in rural northeastern South Dakota with a 108 year history of preparing students to become classroom teachers, counselors, and school principals. The mission of the NSU Teacher Induction Program is to serve as a follow-up program to help first-year teachers adjust to the education profession. It also serves to educate graduating seniors majoring in elementary and secondary education to help them better understand the traits and skills that South Dakota K-12 principals look for when hiring new teachers for their classrooms.

The study was conducted by asking South Dakota school principals to rank professional teaching traits and skills they considered most important for the future success of first-year teachers. A data base of 45 preferred teacher traits and skills was created by collecting examples through various internet resources, local education professionals, and by sending e-mails to a small pool of current school principals to offer their own suggestions of traits they considered important. The collection of 45 traits and skills was then sorted and divided into the following four domains.

\section{- $\quad$ Personal Traits and Skills \\ - $\quad$ Professional Traits and Skills \\ - $\quad$ School-Wide Traits and Skills \\ - $\quad$ Classroom Traits and Skills}

After the pool of traits and skills was collected and divided into four domains, the internet site Survey Monkey was used to create the final electronic survey. Principals were asked to rate each of the 45 teaching traits as 1) Not Important, 2) Somewhat Important, 3) Important, or 4) Highly Important. Four South Dakota school principals from Aberdeen O.M. Tiffany and Lincoln Elementary Schools, Warner High School, and Selby Area Schools served as a pilot group to review the study, take the pilot survey, and offer suggestions for further changes. The survey was then e-mailed to 84 school principals across South Dakota, and 45 principals responded.

\section{FINDINGS}

\section{Domain One: Personal Traits and Skills}

Table 1 identifies eleven personal traits and skills that school principals considered essential when hiring first-year teachers. One-hundred percent of school principals agreed that dependability, a sense of responsibility, honesty, punctuality, trustworthiness, and emotional stability were either important or highly important personal traits for first-year teachers. Maturity (97.8) and loyalty (91.1) were other traits that principals thought were either important or highly important. Eighty-eight percent of principals thought a genuine/authentic personality and personal confidence were also important to success in education. Seventy-five percent of principals rated a sense of humor as somewhat important or important. No principal identified any traits and skills in this domain as unimportant. 
Table 1: Personal Traits and Skills

\begin{tabular}{lccccc}
\hline Personal Traits and Skills & $\begin{array}{c}\text { Not } \\
\text { Important }\end{array}$ & $\begin{array}{c}\text { Somewhat } \\
\text { Important }\end{array}$ & Important & $\begin{array}{c}\text { Highly } \\
\text { Important }\end{array}$ \\
\hline Dependability & 0 & 0 & 6.7 & 93.3 & 100 \\
Sense of Responsibility & 0 & 0 & 8.9 & 91.1 & 100 \\
Personal Confidence & 0 & 11.1 & 60 & 28.9 & 100 \\
Sense of Loyalty & 0 & 8.9 & 42.2 & 48.9 & 100 \\
Honesty & 0 & 0 & 6.8 & 93.2 & 100 \\
Punctuality & 0 & 0 & 37.2 & 62.8 & 100 \\
Maturity & 0 & 2.2 & 51.1 & 46.7 & 100 \\
Trustworthiness & 0 & 0 & 15.6 & 84.4 & 100 \\
Sense of Humor & 0 & 33.3 & 42.2 & 24.4 & 99.9 \\
Genuine/Authentic Personality & 0 & 11.1 & 35.6 & 53.3 & 100 \\
Emotional Stability & 0 & 0 & 28.9 & 71.1 & 100 \\
\hline
\end{tabular}

\section{Domain Two: Professional Traits and Skills}

Table 2 identifies ten professional traits and skills that school principals would most want in their new teachers. One-hundred percent of school principals said communication skills and a commitment to education were either important or highly important traits. At least 91 percent of principals also rated flexibility, organizational skills, good interpersonal skills, and professional growth as either important or highly important. A majority of South Dakota school principals said student teaching references, either from the student's university program advisor or from the cooperating teacher assigned in the field experience, were not highly important to them. Surprisingly, despite a reported chronic shortage of coaches and activity supervisors in their schools, only 13.3 percent of South Dakota principals thought the ability to direct school activities was a highly important professional trait or skill for first-year teachers. No principal identified any professional traits and skills as largely unimportant, but 2.2 percent did rate commitment to good health as not important.

Table 2: Professional Traits and Skills

\begin{tabular}{lccccc}
\hline Professional Traits \& Skills & Not Important & $\begin{array}{c}\text { Somewhat } \\
\text { Important }\end{array}$ & Important & $\begin{array}{c}\text { Highly } \\
\text { Important }\end{array}$ \\
\hline Organizational Skills & 0 & 4.4 & 44.4 & 51.1 & 99.9 \\
Flexibility & 0 & 2.2 & 53.3 & 44.4 & 99.9 \\
Professional Growth & 0 & 8.9 & 64.4 & 26.7 & 100 \\
Communication Skills & 0 & 0 & 40 & 60 & 100 \\
Commitment to Education & 0 & 0 & 33.3 & 66.7 & 100 \\
Commitment to Good Health & 2.2 & 24.4 & 62.2 & 11.1 & 99.9 \\
Good Interpersonal Skills & 0 & 6.7 & 44.4 & 48.9 & 100 \\
Positive Student Teaching References & & & 57.8 & 13.3 & 100 \\
(University Supervisor) & 0 & 28.9 & & & \\
Positive Student Teaching References & & & 50 & 27.3 & 100 \\
(Cooperating Teacher) & 0 & 22.7 & 55.6 & & 100 \\
Ability to Direct School Activities & 0 & 31.1 & & & \\
\hline
\end{tabular}

\section{Domain Three: School-Wide Traits and Skills}

Table 3 identifies twelve school-wide traits and skills that school principals would most want in their new teachers. One-hundred percent of school principals rated enthusiasm, professionalism, teamwork skills, positive attitude, good judgment, and good problem solving skills as either important or highly important. Except for leadership skills, appropriate dress, and understanding diversity, at least 90 percent of South Dakota principals rated all other traits including passion and energy, good decision making skills, and good teacher-parent skills as either important or highly important. 
Table 3: School-Wide Traits and Skills

\begin{tabular}{lccccc}
\hline School Wide Traits \& Skills & Not Important & $\begin{array}{c}\text { Somewhat } \\
\text { Important }\end{array}$ & Important & $\begin{array}{c}\text { Highly } \\
\text { Important }\end{array}$ \\
\hline Enthusiasm & 0 & 0 & 51.1 & 48.9 & 100 \\
Leadership Skills & 0 & 15.6 & 62.2 & 22.2 & 100 \\
Professionalism & 0 & 0 & 24.4 & 75.6 & 100 \\
Teamwork Skills & 0 & 0 & 35.6 & 64.4 & 100 \\
Positive Attitude & 0 & 0 & 22.2 & 77.8 & 100 \\
Passion and Energy & 0 & 2.2 & 37.8 & 60 & 100 \\
Good Judgment & 0 & 0 & 46.7 & 53.3 & 100 \\
Appropriate Dress & 0 & 15.6 & 62.2 & 22.2 & 100 \\
Decision Making Skills & 0 & 4.4 & 51.1 & 44.4 & 99.9 \\
Problem Solving Skills & 0 & 0 & 53.3 & 46.7 & 100 \\
Teacher-Parent Skills & 0 & 4.4 & 42.2 & 53.3 & 99.9 \\
Understanding Diversity & 0 & 15.6 & 51.1 & 33.3 & 100 \\
\hline
\end{tabular}

\section{Domain Four: Classroom Traits \& Skills}

Table 4 identifies twelve classroom traits and skills that school principals would most want in their new teachers. South Dakota school principals rated classroom management skills, planning and preparation, purposeful lessons, and respect for students as important or highly important. At least 95 percent of school principals also rated class time management, classroom atmosphere, knowledge of student special needs, and content knowledge as important or highly important. Ninety-three percent of principals rated creativity as either important or highly important, but only 13.3 percent of principals thought knowledge of educational theory was highly important. When considering student-teacher relationships, 71.1 percent of principals thought respect for students was highly important, but only 22.2 percent thought friendliness with students was highly important. Finally, only 18.2 percent of South Dakota principals believed technology skills were highly important.

Table 4: Classroom Traits \& Skills

\begin{tabular}{lccccc}
\hline Classroom Traits and Skills & Not Important & $\begin{array}{c}\text { Somewhat } \\
\text { Important }\end{array}$ & Important & $\begin{array}{c}\text { Highly } \\
\text { Important }\end{array}$ \\
\hline Pleasant Class Atmosphere & 0 & 2.2 & 57.8 & 40 & 100 \\
Content Knowledge & 0 & 4.4 & 66.7 & 28.9 & 100 \\
Classroom Management & 0 & 0 & 28.9 & 71.1 & 100 \\
Knowledge of Education Theory & 2.2 & 20 & 64.4 & 13.3 & 99.9 \\
Class Time Management & 0 & 2.2 & 44.4 & 53.3 & 99.9 \\
Planning and Preparation & 0 & 0 & 51.2 & 48.8 & 100 \\
Creativity & 0 & 6.7 & 68.9 & 24.4 & 100 \\
Purposeful Lessons & 0 & 0 & 37.8 & 62.2 & 100 \\
Friendliness with Students & 2.2 & 15.6 & 60 & 22.2 & 100 \\
Respect for Students & 0 & 0 & 28.9 & 71.1 & 100 \\
Technology Skills & 0 & 11.4 & 70.5 & 18.2 & 100.1 \\
Understanding Special Needs & 0 & 2.2 & 37.8 & 60 & 100 \\
\hline
\end{tabular}

\section{CONCLUSIONS}

South Dakota elementary and secondary school principals participating in this study indentified the following sets of traits and skills as the highest rated characteristics for first-year teachers to practice:

\section{Domain One: Personal Traits and Skills}

- Sense of Responsibility

- Honesty

- Punctuality

- Trustworthiness

- Emotional Stability

\section{Domain Two: Professional Traits and Skills}

- Communication Skills

- Commitment to Education 


\section{Domain Three: School-Wide Traits and Skills}

- Enthusiasm

- Professionalism

- Positive Attitude

- Good Judgment

- Strong Problem Solving Skills

\section{Domain Four: Classroom Traits and Skills}

- Classroom Management Skills

- Planning and Preparation

- Purposeful Lessons

- Respect for Students

Research indicates that school principals in general are seeking evidence of a baseline set of skills from the first-year teachers they hire. Typically, principals want new teachers that have a passion for education, a strong desire to work with students, and high quality interpersonal skills to connect with both other professionals in their schools and parents in the school community. Principals in South Dakota schools agreed that they also want firstyear teachers that have a genuine personality, a passion for teaching their students, and positive attitudes. South Dakota principals want teachers who possess a strong work ethic and good planning and organizational skills to meet the growing demands of the changing school curriculum and technology needs in the modern school classroom.

Finally, research shows principals may like to hire new teachers that share similar sets of values, dispositions, and standards that they have. Becky Roth, Principal at L.B. Williams Elementary School in Mitchell, South Dakota said, "Most of all, we look for people who will not only have the skills and knowledge we value, but to teach their subject areas with creativity and be team players willing to collaborate with colleagues that want to continually grow as professionals. When a first-year teacher is learning the ropes, I look forward to molding them into the type of teacher-leaders we want in our school district in the years to come."

\section{AUTHOR INFORMATION}

Craig D. Kono has served as classroom teacher, high school principal, and school superintendent in K-12 South Dakota schools from 1979 to 2001. He received his Bachelor's Degree in Secondary Education 1979 and his Masters Degree in Secondary Administration in 1988 from Northern State University in Aberdeen, South Dakota. He earned his Specialist Degree in school district administration in 1998, and his Doctor's Degree in Educational Administration from the University of South Dakota in 2001. Currently he is an Associate Professor of Educational Administration at Northern State University in Aberdeen, South Dakota preparing graduate students for careers in elementary and secondary administration. He also serves as coordinator and supervisor for the Northern State University Teacher Induction program which provides assistance to first-year teachers in education.

\section{REFERENCES}

1. Broadley, G. \& K. (2003). Principals Hire Beginning Teachers They Like. New Zealand Principal Federation Newsletter, Wellington NZ

2. Hopkins, Gary (2009). What Qualities Do Principals Look for in a New Teacher ?. Education World.Com. Retrieved 2/12/2009 from http://www.educationworld.com/a_admin/admin/admin071.shtml

3. Shaw, D.G. (2003). More About What Principals Want. New Teacher Advocate Newsletter, Anchorage, AK.

4. Glenn, R.E. (2001). Admirable Teaching Traits. National Education Association, Washington DC. 